Маленицька, Ольга. «Лінгвоексплікація внутрішнього стану героя в драматичній поемі Лесі Українки “На полі крові"». Лінгвостилістичні студії, вип. 12, 2020, с. 117-29.

Malenytska, Olga. "Linguistic Explication of the Hero's Inner State in Lesya Ukrainka's Dramatic Poem "In the Field of Blood"'. Linguostylistic Studies, iss. 12, 2020, pp. 117-29.

Удк 811.161.2'367'38+821.161.2'05-12.09Українка

https://doi.org/10.29038/2413-0923-2020-12-117-129

\title{
ЛІНГВОЕКСПЛІКАЦІЯ ВНУТРІШНЬОГО СТАНУ ГЕРОЯ В ДРАМАТИЧНІЙ ПОЕМІ ЛЕСІ УКРАЇНКИ «НА ПОЛІ КРОВІ»
}

\author{
Ольга Маленицька \\ Східноєвропейський національний університет імені Лесі Українки, \\ Луцьк, Україна
}

У статті досліджено авторські засоби мовного вияву психології героя як однієї з визначальних ознак індивідуального стилю Лесі Українки. Проаналізовано вербальні й невербальні інструменти розгортання письменницею світу почуттів та емоцій персонажа. Встановлено особливості відтворення динаміки психо-емоційних станів у ремарках і мовленні самого героя на лексичному й морфологічному рівнях, а також синтаксичні й стилістичні прийоми висвітлення мотивів поведінки героя.

Ключові слова: психічний стан, авторський коментар, мова героя, мовні засоби, невербальні засоби, вербалізація почутів.

\section{LINGUISTIC EXPLICATION OF THE HERO'S INNER STATE IN LESYA UKRAINKA'S DRAMATIC POEM “IN THE FIELD OF BLOOD” Olga Malenytska \\ Lesya Ukrainka Eastern European National University, Lutsk, Ukraine}

The article highlights the peculiarities of the linguistic presentation of the hero's inner state and considers it as one of the Lesia Ukrainka's idiosyncrasy. On the material of the dramatic poem In the Field of Blood, the author traces the ways and means of linguistic disclosure of the Bible character Judas' feelings and sufferings after the betrayal. The purpose of the research is to reveal the features of the linguistic objectification of the psychological state of the hero and the stylistic motivation of using them in the individual author's style. It appears a marker of the poetess's innovation in the context of the early twentieth century trends and inquiries. The method of associative-conceptual analysis was applied to measure the semantic capacity and stylistic loading of the fixed lexemes. The dynamics of the mental states are presented in the author's comments and the main character's speech. The means to convey feelings expression in the author's directions/remarks include extralinguistic means (silence, pauses, laughter, a tempo of speech, voice and intonation), play on words, and description of the dynamic expressiveness. Verbal tools for expressing emotions are presented on lexical, grammatical, and stylistic levels. In Judas' speech, emotionality is conveyed by colloquial words, phraseologisms with negative markers, the size and structure of remarks/replicas, exclamatory statements, objections, and rhetorical figures. Emotional comparisons, colorful and vivid epithets in characterization, much attention to the semantics of lexemes, and their author's connotation testify to the mastery of Lesya Ukrainka in the linguistic development of the psycho-emotional state of the hero. The state of depression,

(C) Маленицька О., Східноєвропейський національний університет імені Лесі Українки, 2020.

Це стаття відкритого доступу на умовах CC BY-NC 4.0 
exaltation, affect at the syntactic level is reproduced by remarks, different in size, structure, and complexity, in the form of exclamations, statements, objections, and rhetorical questions.

Key words: mental state, character's language, language means, non-verbal means, verbalization of feelings.

Вступ. Так уже складається, що рубіж віків - це час найактивніших шукань митців, котрі, не бажаючи далі йти втоптаними стежками, переосмислюють досвід попередників, аби з нього генерувати нові ідеї та свіжі погляди на усталені поняття й норми (згадаймо модернізм кінця XIXпочатку XX ст. і постмодернізм межі XX-XXI ст.). Саме на час порубіжжя й припадає розквіт творчості Лесі Українки, а написана в кінці першого десятиліття нового сторіччя драматична поема «На полі крові» (1909 рік) бачиться плодом пошуків, позначених прагненням відійти від реалістичної манери об'єктивної сюжетності з детальним вимальовуванням персонажів й запропонувати дещо нове - зазирнути за зовнішну оболонку образу, в глибини душі особи, зрозуміти мотиви ї̈ дій. «Інтерес літератури порубіжжя до “аномалій життя” - усього не шеренгового / ненормального зумовлювався, зауважує С. Романов, якраз-таки не зіпсутістю моралі письменника, як то увижалось українській публіці. Головними були <...> тенденції часу, зокрема приголомшуючі відкриття у сфері психології і загалом внутрішнього світу людини. Очевидно, що процес цей коли не синхронно, то цілком паралельно йшов i річищем науки, i шляхами мистецтва. I останнє не рідко виступає <..> інтуїтивним провісником і несхибним провідником першого» (Романов 354).

Закономірно, що звертаючись до канонічної біблійної теми (як, до речі, й І. Франко в поемі «Мойсей»), Леся Українка представляє її власне осмислення. Резонуючи з віяннями часу, вона віддаляється від традиційного для християнства уникнення розмов про Юду й пропонує сміливий модерний погляд на складну історико-філософську й моральноетичну проблему. Ї̈̈ цікавить психологія особи, що вчинила зраду. Як живеться людині після такого вчинку, що спонукало їі до цього, що відчуває вона, звідки бере силу протистояти загальному осудові - ось ті питання, відповіді на які дошукує авторка драматичної поеми «На полі крові». I якщо літературознавці намагаються осмислити місце поетичної драматургії Лесі Українки і її проблематики в контексті доби (В. Агеєва, В. Антофійчук, Н. Банадська, І. Бетко, І. Качуровський, Л. Масенко, М. Моклиця, Є. Ненадкевич, В. Панченко, С. Романов, Г. Смирнова, А Шамрай та ін.), то інтерес лінгвістів полягає в пізнанні мовних ресурсів, посередництвом яких письменниця реалізує творчі задуми й вибудовує мовно-образну картину світу.

Мета дослідження - з'ясувати способи й засоби мовної об'єктивації психологічного стану героя, їх стилістичну вмотивованість як ознаку індивідуально-авторської мовної манери Лесі Українки.

Матеріал і методи дослідження. Матеріалом дослідження слугував текст драматичної поеми Лесі Українки «На полі крові». У ході дослідження 
застосовано метод асоціативно-концептуального аналізу для виміру семантичної місткості й стилістичної навантаженості фіксованих лексем; метод лінгвопоетичної інтерпретації для «тлумачення змісту тексту на основі розкриття системно-семантичних відношень мовних одиниць різних рівнів» (Богдан 18); лінгвістичного експерименту й комплексного аналізу з метою окреслення властивих Лесі Українці способів лінгвопрезентації психо-емоційного стану.

Результати дослідження та дискусія. Цілковито поділяючи думку про те, що «не було літературознавця, критика, який би не точив перо на огнистому камені Лесиної поезї̈» (Мацько, і Сидоренко 136), маємо підстави продовжити її твердженням, що так само не знайдемо й мовознавця, якого б обминуло бажання посмакувати із джерела Лесиної мови. Тільки впродовж останніх п'яти-шести років можемо назвати кілька десятків публікацій, спрямованих на окреслення мовної картини світу Лесі Українки та їі індивідуально-авторських мовних уподобань у творенні художніх образів. Увагу дослідників привертає лексичний обшир поетеси, зокрема народнорозмовна й діалектна лексика, ономастикон i кольороназви (Н.Дмитренко, С.Локайчук, I. Скорук А.Яворський), номінанти сакрально-демонологічного, етнокультурного простору й фраземіка (Г. Вишневська, О. Маленицька, З. Мацюк, Л. Павленко, М. Фенко та ін.). Шукання мовознавців спрямовані на осягнення мовотворчості письменниці, семантичного простору концептів (Т. Вільчинська, Г. Вокальчук, Т. Коць, Л. Мацько, Н. Мех, О. Сидоренко), емоційного й естетичного навантаження (Н. Данилюк, М. Зубрицька та ін.) й стилістичної ролі граматичних одиниць, особливостей синтаксису, пунктуації й невербальних засобів у поетичній, епістолярній та публіцистичній спадщині Лесі Українки (Н. Бабич, С. Богдан, О. Гандзюк, О. Даскалюк, І. Левчук, Т. Масицька, О. Масло, Н. Приходько та ін.).

Філософія Ніцше 3 його «неприємними істинами» (концепція надлюдини, що розкривалась через гостру критику християнства, розуміння сенсу життя як прагнення до влади) не могла розминутися 3 акумулючою все нове неординарною особистістю Лесі Українки. Слушною з цього приводу видається думка про те, що «погляди “бентежного німця” на природу релігії, суспільства, людини, сміливі стилістичні експерименти 3 єдністю художнього й філософського наративів коли не трансформувалися у творчих шуканнях Лесі Українки безпосередньо, то збурювали, стимулювали, урізноманітнювали їх. Варто хоча б пригадати переосмислення християнських догматів у їі драмах або ж особливості характеротворення їхніх героїв у вимірі вольових первнів поведінки та почувань» (Романов 97). Відтак стає зрозумілим, що таке творче резонування поетеси на запити доби стимулювало й процес пошуку мовної об'єктивації не стільки самих вчинків персонажів (що саме вони зробили), скільки прихованих від стороннього ока, але таких актуальних для 
тогочасного читача внутрішніх мотивів їх дій і психо-емоційних станів (чому вони це зробили і що відчувають).

Аналізуючи розгортання психології Юди (на початку у твору його названо Чоловіком) як центрального персонажа драматичної поеми «На полі крові», помічаємо, що письменниця вдається до двопланової мовної маніфестації: через авторські коментарі для актора/читача, тобто ремарки, і через мовлення самого героя. До того ж в обох способах авторка використовує як вербальні, так невербальні інструменти.

Тяжкий душевний стан героя задекларовано уже в першій ремарці через прикметникове портретування: з природи кремезний та тривкий Ч о л о в і к худий і зниділий (Українка 322). Лексичне значення слова 'зниділий' у мові того часу можемо встановити за словником Бориса Грінченка, де його витлумачено як «зачахнувшій, исхудалый» (Словарь 2: 173). I хоч причини фізичного виснаження не названо, прагнення до усамітнення, уникнення не тільки мовного спілкування, але й візуального контакту, свідчить про депресію, яку досить точно передає ампліфікація дієслівних конструкцій уже на початку твору: Працівник мовчить, не одривається од роботи і не дивиться на прочанина; показує на кухоль 3 водою; не подає знаку, що чув ці слова (Українка 322). В ситуації, коли Прочанин, вдивляючись, пізнає в ньому зрадника, знаходимо авторський коментар, що засвідчує душевну смуту Юди: тому, очевидячки, тяжске те вдивляння (Українка 327).

Емоції, стверджують психологи, виконують роль внутрішніх сигналів, «особливість яких полягає в тому, що вони безпосередньо виражають відношення між мотивами й реалізацією, яка відповідає цим мотивам діяльності» (Леонтьев 194). Мовчання й паузи у творчій майстерні Лесі Українки - це інструменти розкриття внутрішнього стану героя. I якщо в ремарці перед початком одкровення Юди авторка зазначає, що той мовчить якийсь час <...>, а згодом робить паузу (Українка 331), то далі уже сам герой, використовує мовчання як маніфестацію мотивів власної поведінки, виправдовуючи причини свого першозламу, що передував i, зрештою, призвів до зради Христа. Із тексту дізнаємось, що далеко не бідний Юда торгує, ворогує, судиться з сусідами за маєтності і, природно, шукає швидкого шляху придбати для себе Царство Боже (Українка 333), але, отримавши неочікувану пораду роздати маєтності бідним, пояснює свою реакцію: Я мовчки / від нього відступив. Тяжским здалося / мені те слово. <...> Бо хто він був? Син теслі. Що він мав? / Нічого зроду <..> (Українка 333). Так єдиною лексемою мовчки письменниця досягає подвійного ефекту: передає не тільки розчарування, але й мотив його виникнення - властиву маєтній людині потребу самозвеличення, зверхності над кимось й використання влади для задоволення власних амбіцій.

Відомо, що емоції відносно слабко виявляються в зовнішній поведінці людини. Найчастіше людина приховує їх, вдаючись до мовчання 
як способу маскування емоційного стану. Однак, у творі Лесі Українки мовчання має й додаткову функцію - слугувати тлом, яке відтінює ці приховані емоції. Наприклад, сум'яття, передане мовчанням, контрастує 3 одночасним прагненням вивільнитись від мук совісті через вибух стримуваних емоцій. На запитання Прочанина, як саме втратив свій статок, інтравертний Юда мовчить якийсь час, поглядаючи на прочанина, мов вагаючися звірятись йому, далі не видержсу, і мова його проривається прудким, часто безладним потоком (Українка 331).

Цікаво, що навіть у ремарках, котрі в драматичному творі покликані слугувати 'технічним' коментарем для режисера й акторів, Леся Українка вдається до засобів образності. Силу гніву, що розриває героя, вона коментує не звичними, здавалося б, для ремарок конструкціями із прислівниками дуже, сильно, надто і под., а експресивно навантаженими одиницями - метафорою проривається і модельованим у формі орудного відмінка зіставленням характеру мовлення персонажа 3 нестримно бурхливим потоком води, що зносить усе на своєму шляху, конкретизуючи його епітетами прудкий і безладний. Витримуючи канони драматургії й наставляючи акторів на адекватне авторському замислові сценічне відтворення образу, письменниця, як бачимо, не тільки не нехтує законами ліро-епічного жанру, але й дбає про читача, через вишукані образи уможливлюючи глибину емоційного переживання й естетичної насолоди від сприймання тексту. Така особливість ремарок, що її можемо простежити й в інших драматичних творах Лесі Українки, щонайкраще, на наш погляд, презентує сутність своєрідності мовної манери творця модерної української драматургїі.

До ряду екстралінгвальних інструментів експлікації внутрішнього стану героя, крім мовчання й пауз, письменниця долучає ще й сміх. Гнівне обурення Юди, що спалахнув, видає короткий злісний сміх (Українка 330). Так само сміх вихлюпує розчарування від несправджених сподівань на обіцяні блага (з коротким сміхом) / Не так се просто! Він бач, говорив, / що тільки з ним увійдем в Царство Боже, / без нього ж - ані до порога! (Українка 333).

Емоційно-почуттєвий стан особистості, що протиставила себе загальноприйнятим нормам моралі, Леся Українка презентує й через просодичні ознаки. У ремарках знаходимо зауваги щодо зміни голосових та інтонаційних характеристик мовлення як індикаторів емоційних коливань: поспішно (Українка 323), неохоче - неохоче - 3 понурим глузуванням - злісно - шорстко (Українка 324); поспішно - мов з острахом (Українка 325); збентежено (Українка 326); з притиском - спалахнув похмуро (Українка 330); уперто - люто - поспішно - з крайнім презирством (Українка 340).

Особливо показовою є різка зміна особливостей голосу, викликаних реплікою Прочанина: Тепер я бачу добре: ти той Юда, / що Вчителя продав. Лексема-подразник 'продав' викликає в героя бурхливу реакцію широкої 
амплітуди: від пригніченості - до агресії, що має об’єктивуватися в його мовленні: з одвагою безвихідності зміняє свою дотеперішню понуропотайну гутірку на рішучу, до нахабності одверту (Українка 327).

Як відомо, дядько Лесі, наймолодший брат Олени Пчілки Олександр Драгоманов, був лікарем-психіатром і 1986 року захистив докторат із психіатрії. Впродовж 1892-1899 років Леся Українка кілька разів відвідувала містечко Творки, де в клініці для душевнохворих працював «дядя Саша» i, безперечно, мала можливість спостерігати за його пацієнтами, про що з гумором згадувала в листі до Лідії ДрагомановоїШиманової: «Коли ти думаєш по сих листах, що у мене в голові “не всі дома", то нема нічого дивного, бо я тільки недавно вернулась із сумашедшого дома, куди їздила в гості до дяді Саші» (Косач-Кривинюк 357). Відтак не дивно, що навіть тривалість і темп мовлення для письменниці слугують виразниками психічного стану персонажа.

До прикладу, на початку твору, в мовленні Юди домінують короткі речення і навіть обривчасті фрази: Он там...є ще вода... ти хтів сповнити / сю тикву на дорогу... дай, наллю... / <... Ну от... Іди собі... і не кажи / нічого більше... я зовсім не хочу / твого благословення... я не хочу... (Українка 325). Апосіопеза, тобто незавершеність фрази, може бути зумовлена, як пояснює В. Святовець, «особливою схвильованістю, переживанням персонажа; несподіваним приєднанням до розмови небажаної особи; <..> приховуванням думки дійової особи 3 огляду на політичні чи етичні мотиви; перебуванням персонажа у стані великого фізичного виснаження, депресії, переляку тощо» (Словник тропів 27). Саме таким ми й бачимо Юду. Схвильований розпитуваннями Прочанина, він намагається приховати свої думки і вчинок, тому й відповідає обірваними фразами. Далі в залежності від наростання емоційності персонажа змінюється темп мовлення. І вже захоплений власними спогадами, Юда не зважає на спробу Прочанина долучитися до розмови. Саме цей таке мовлення авторка й називає прудким, часто безладним потоком (Українка 331) і далі додає ремарку: не слухає його, тобто Прочанина (Українка 332). В описаній ситуації легко пізнаємо екзальтацію - «збуджений стан, іноді самочинно викликаний; надмірна захопленість. У психіатрії - стан збудження без затьмарення свідомості» (Словник іншомовних 188).

У зовнішній маніфестації почувань героя важливу роль відіграє прийом мовної гри. Інтонаційний малюнок, що підкреслює роздратування й міру зневаги, Леся Українка передає через імітацію, пародіювання Юдою голосу Вчителя, від чого самі слова набувають протилежної семантики: (Наслідує чийсь голос.) / Лукавий! Маловіре! (Українка 329). Так само зневажливо-саркастично звучить репліка Жий, рибонько! Нащо тобі вода? / Глянь на пташки небесні у повітрі! / Чи ж їм не добре там?, якій передує ремарка: Очевидно, імпровізує пародію на чиюсь промову (Українка 330).

Ключем до розуміння внутрішнього стану бачиться й розгортання динамічної експресії персонажа. Так, наприклад, страх Юди бути 
впізнаним учнем Ісуса передано у творі коментарем щодо міміки й погляду (здригнувся $і$ спустив очі (Українка 325), а розчарування й лють невдоволеного багатія за оприлюднення його ганебного вчинку (Сьогодні зрадник хліб вмочає з нами) в картині Тайної вечері передано дієслівним описом: Задумується. Потім здіймає голову вгору (Українка 339). Наступна репліка Що він посіяв, те й пожав! Сам винен! влучно характеризує зверхність особи, яка дошукується виправдання хоча б перед собою.

Значно ширший простір почувань розкривають виразові рухи героя. Скажімо, те, що він Показує мотикою <...> і знов нахиляється до праці (Українка 323), свідчить про природне бажання нервово виснаженої людини уникнути розмови, його стан видають нетерплячі рухи (Українка 325), які $\epsilon$ закономірним наслідком стримування емоцій. Активний контрнаступ як спосіб захистити себе за відсутності аргументів ілюструє заувага письменниці поступаючи до прочанина (Українка 327) в значенні 'агресивно наступаючи на нього'. Ремарка свідчить про граничний рівень нервової напруги, властивий станові афекту - тобто психічної реакції, що виникає як наслідок уже звершеного дії чи вчинку і являє ії суб’єктивний емоційний відгук, обумовлений мірою досягнення поставленої мети. Саме на такий стан зумовлюють часту немотивовану й неусвідомлювану зміну дій, пози тіла, жестів, на що вказує письменниця через детальний опис виразових рухів героя: загарливо копає землю; кинув мотику, зложив руки на грудях. Випростався (Українка 328); Хапає знов мотику і злісно б'є по твердій землі, крешучи іскри з каміння (Українка 329); знов кидає роботу (Українка 329).

Досить промовистою в плані психологічної характеристики $\epsilon$ волинізм загарливо. У словнику Бориса Грінченка 'загарливий' пояснюється як “усердный, горячій въ работь” з приміткою “НВолин. у.”, тобто Новоград-Волинський уїзд (Словарь 2: 25). Так пізнане Лесею ще 3 дитинства слово виявляється найбільш семантично містким для відтворення нервового стану героя і після його морального зламу.

Успішне завершення певної дії, пояснюють психологи, саме собою не гарантує позитивної емоції, але «може спричинити тяжке емоційне переживання, яке гостро сигналізує про те, що з боку мотиваційної сфери людини досягнутий успіх обернувся поразкою» (Леонтьев 194). Подібне вбачаємо і в ситуації з Юдою. Глибокий емоційний дискомфорт героя передаєно дієслівним описом малоусвідомлених і невмотивованих поведінкових реакцій у фінальній сцені драматичної поеми: Юда стоїть хвилинку, стиснувши голову руками, далі стукає себе кулаком по голові, хапає мотику $і$, не розгинаючись, не втираючи поту, працює до нестями (Українка 342).

Репрезентантом психо-емоційного стану безумовно $\epsilon$ особистий словник Юди. Психологію маєтної людини, сповненої зневаги до простолюду, відтворює просторічна лексика, що її використовує персонаж 
для йменування осіб, з якими йому довелось спілкуватися, як-от: дурень, гульвіси, повії, жебраки, попихач, старці, голота (Дурень той або злочинещь, /хто дарма віддає (Українка 327); Вже краще б я пропив ту батьківщину / з гульвісами, з повіями (Українка 329); Просити хліба у тії голоти, / що з рук моїх добро моє посіла? (Українка 336); Голотою каріотською щонайгіршою (Українка 334)). Царством глуму й відметами Юда називає послідовників Христа: хоч день $і$ ніч я голову сушив, / як вирватися з того царства глуму, де не мені народи слугували, / а я служив відметам всіх народів (Українка 338).

Цікаво, що в лексикографічних джерелах, зокрема словнику Бориса Грінченка, лексеми 'відмети' не зафіксовано, знаходимо лише дієслово 'відмітати' з приміткою «сов.в.» (сучасний варіант. - О. М.), одне зі значень якого - «отбрасывать, обросить» (Словарь української 1: 220), тобто відкидати, відкинути. Очевидно, що в процесі лінгвалізації моральної сутності персонажа Леся Українка утворює похідний від дієслова 'відмітати' іменник відмети, що відповідає сучасному зневажливому 'покидьки', тобто «морально розкладені люди, декласовані, злочинні елементи суспільства; непотріб, негідь, потолоч» (Новий тлумачний 3: 525). Можемо припустити, що ця лексема $є$ новотвором письменниці, оскільки ії не фіксують лексикографічні джерела ні як самостійну одиницю, ні як варіант.

Ілюстраторами психічного стану є компаративні конструкції, що їх авторка вводить до мови героя. Гурт людей, що супроводжували Учителя, він порівнює із 'меткою'. Семантику цієї лексеми Борис Грінченко пояснює як «нанизаный рядъ (рыбы, напр.)» (Словарь 2: 420). I хоч для назви гурту чи ряду людей або тварин в мовленні того часу використовували ще й лексему 'вервечка', що засвідчує вказане вище лексикографічне джерело (Словарь 1:134), Леся Українка, однак, в уста персонажа вкладає саме першу: Я дбав про харч, про хату / для гурту цілого і про старців, / що меткою за нами волочились (Українка 336). Можемо припустити, що причиною саме такого вибору могли бути різні фактори. 3 одного боку порівняння гурту людей з низанкою риби вітворювало реалії, в яких відбувалась дія, адже Ісус проповідував у Галілеї й багато його учнів були простими рибалками. Тому природним видається використання одним із них лексеми, що широко вживана в професійному мовленні. Слово 'вервечка', окрім вказаних лексикографами значень, як зменшувальне від 'вервиця' використовується ще й у церковній термінології на позначення «замкненої мотузки із зав'язаними вузлами чи нанизаними на неї кульками, призначеної для відрахування прочитаних молитов та здійснення поклонів», що $\epsilon$ відзнакою ченців, але використовується й мирянами та має синонімічну назву 'чотки' (Пуряєва 33). Будучи далекими від думки, що Леся Українка не знала про існування цього атрибута і його назви, можемо припустити, що саме стилістичне нашарування з відтінком негативності зумовило вибір лексеми 'метка' як об'єкта порівняння, 3 
метою відобразити почуття зневаги і зверхності заможної особи над простим людом.

Так само промовистими є конструкції, в яких об'єкт порівняння представлено лексемами 'пес', 'собака' 3 властивою просторічному мовленню негативною конотацією: Він звик, щоб ми, як песики, лагідно / йому дивились в вічі (Українка 338), а сам голодний, збіганий, як пес (Українка 336), Жінки, як ті собаки, - раз погладь, / а потім хоч щодня лупцюй, все стерплять!/ Та й руки ще лизатимуть... (Українка 337).

Надмір роздратування й напади гніву багатія (Я спадок мав від батька: виногради / $і$ ниву добру, $і$ садок, $і$ дім. / Все мав я в Каріоті. (Українка 329)), що не здобув бажаної влади й почувається приниженим, репрезентують лексичні експресиви, позначені відтінком лайливості. Пожертви, що їх приносили вірні, Юда зневажливо називає жебрацьким, жебраним хлібом, недоїдками (Українка 328; 334), торбою і хавтурками: Яку я втіху мав? За жебраками / носити торбу, хавтурки збирати, попихачем їм буть ні за спасибі! (Українка 329).

Особливу функцію в розгортанні сили негативних емоцій, що мотивують зрадницький вчинок, на наш погляд, відведено лексемі 'хавтурки', що, як і попередньо аналізована 'відмети', $\epsilon$ похідною. Утворений від іменника чоловічого роду 'хавтур' або варіанта жіного роду 'хавтура' зі наченнями хабар, побори натурою чи залишки поминального обіду, які збирало духівництво й біднота (Словарь 4: 382-383; Новий тлумачний 4: 710), посередництвом суфікса -к демінутив 'хавтурки' в тексті драматичної поеми набуває вже виразно негативного маркування й стає демонстратором глибини внутрішньої напруги героя.

Зіставлення контрастних образів 3 нанизування епітетних характеристик негативного й позитивного маркування - ще один із властивих Лесі Українці прийомів лінгвоексплікації емоційних відчуттів. У картинах, що їх малює уява Юди, бачимо глибину протиріч його свідомості й визрівання заздрості як причини зради. Чималий батьківський спадок стає немилим: тісна мені здалася хата, / мізерні клуні, й тік, і двір нудний / виногради навіть невеселі. Його манить райська брама, золотий престол, гурт обранців щасливих, радісних, безмежсна щастя їхнього облада (Українка 334).

Вербальний простір, що виявляє психічний стан мовця, доповнює ряд дієслів прозорої негативної семантики (базікать, ограбував, обдурив, волочились, витріщались, обридло), як-от: Мені ніколи з тобою базікать (Українка 324); Я дбав <...> і про старців, / що меткою за нами волочились (Українка 36); але всі навколо / на мене витріщалися одразу (Українка 339); Мені вже все обридло (Українка 339).

Динаміку емоційності презентують i фразеологічні одиниці в мовленні персонажа. На початку твору, заглиблений у власні переживання, Чоловік не багатослівний. Наростання сили розбудженого в процесі комунікації гніву й невдоволення бачимо у збільшенні кількості фразем 3 
негативним експресивно-емоційним навантаженням, як у коментарі Юди щодо проповіді Вчителя: Таж начувся / ї̈ доволі! Через вуха ллється! / Вилазить боком досі...(Українка 330). Психічна напруга зростає - й далі репліка Що він посіяв, те й пожав! Сам винен! (Українка 339), що вказує на стан афекту. «Розвиток афекту, - пояснює Р. Нємов, - підпорядкований такому законові: чим сильніший мотиваційний стимул поведінки і чим більше зусиль довелось затратити на те, щоб його реалізувати, чим менший підсумок, отриманий в результаті всього цього, тим сильнішим $\epsilon$ виниклий афект» (Немов 208-209). Фразеологічні вирази 'вдарити по руках' і 'віддати з рук в руки', властиві мовленню торгівців, у поєднанні 3 компаративною конструкцією підкреслюють силу афекту в цинічному описі Юдою процесу зради як звичного торгу: Так само продають їх (людей - О. М.), як $і$ все, / як гуси, як худобу: поторгують / $і$ вдарять по руках. Ти ж думав як?/A потім з рук у руки віддають їх / тому, хто купить. Om і все. Не бачив? (Українка 339).

У стані надмірного емоційного напруження, як відомо, людині властиво втрачати контроль над змістом і формою власного мовлення. Такий стан персонажа авторка передає через тривалий та багатослівний монолог героя. Зазнавши зневаги й загального осуду, Юда вдається до емоційного виправдання за активним використанням фразеологічних одиниць: обдерти дався до нитки, до шага; попихачем їм буть ні за спасибі (Українка 329); теє місто далось мені в знаки (Українка 331); зуби зціпивши, їм догоджали; хоч день і ніч я голову сушив (Українка 338); поневірятись, пороги оббиваючи; з рукою довгою, 3 язиком довгим поміж людьми ходити (Українка 328-329). Неконтрольований свідомістю стан афекту ілюструє й нагромадження в монологах фразем, використання яких, зазвичай, дозоване у стані психологічної рівноваги. Апогей обурення й ненависті Юди відтворює використання десяти фразеологізмів впродовж безперервного монологу: Хотів би знати я, що б ти зробив, / якби тобі текли крізь пальці гроші <...>/ а сам голодний, збіганий, як пес, / їв облизні та думкою, як дурень, / мав багатіти...День у день промови,<...> / аж світ макітрився мені від них! / Я їм не бачив ні кінця, ні краю.../<..> а скоро хто було розвісить вуха / <...> тому таке ярмо він клав на шию,/ <...> отож було не смій його спитати/ він зараз попадав у нетерплячку: / що краще б він уже налаяв просто, / ніж так пекти ажс до живого серця (Українка 336-337).

Синтаксичні конструкції реплік героя - ще один зі способів лінгводекодування внутрішнього стану. Аналізуючи їх, помічаємо, як змінюється характер реплік залежно від процесів збудження й гальмування. Спочатку Чоловік вочевидь пригнічений, замкнутий, тому мовлення його представлено короткими уривчастими фразами, що супроводжують його описові рухи: Он, можеш взяти (Українка 322); Туди../<...>Ні.../ Єрусалимський! / Авжеж!.. Хіба, ти думаєш, я звідки? / <...> Авжеж, моє. Чиє ж би мало бути? (Украӥнка 323); Та...недавно /<...> 
Небагато/<..> Як для кого (Українка 324). На свідоме використання авторкою такого прийому для відтворення депресивного стану вказує й те, що навіть Прочанин, який ініціює розмову, помічає неприродність мовлення й зауважує: Ото яка чудна балачка в тебе! (Українка 323). В міру наростання емоційної напруги, змінюються й конструкції реплік. Вони стають більш поширеними й об'ємнішими. Не як яка земля, а як для кого! / Я так сказав, то так і розумій/ <...> Мені не треба твого розуміння. / Напився, відпочив ти - ну й іди./ Мені з тобою ніколи базікать (Українка 324). У час максимального збудження, коли герой, як зазначалось вище, не контролює свідомо своє мовлення, репліки набувають форми великих монологів 3 використанням складних й ускладнених речень, на зразок: Любив, щоб завжди / жінки йому вродливі слугували, - / вони за ним ходили цілим роєм, / а він їм дозволяв, щоб ноги мили / йому коштовним нардом і волоссям / розкішним, як буває у блудниць, / вони йому ті ноги витирали (Українка 326); Все марилось мені то райська брама, / то золотий престол, а на престолі / Месія в образі того промовия, / неначе судить він живих і мертвих... / коло престолу гурт його обранців, / щасливих, радісних, і їм слугують / народи всього світу залюбки.../ безмежна щастя їхнього облада.../ $і$ я їм заздрив... (Українка 334)

Відповідно до теорії афектів, висловленої ще в XVII столітті Бенедиктом Спінозою, сила ненависті до того, ким захоплювалась особа раніше, виявляється тим більше, чим сильнішим було попереднє захоплення цією особою (Спиноза 37). Відтворення такої закономірності спостерігаємо в ампліфікації однорідних членів, що ускладнюють синтагми в монологах Юди: Глянув я на кручу / і там, край ніг промовця, ще завважив / гурток людей, чоловіків, жінок, / усі вони дивились на промовця, / а часом поглядали і на нас / з осяйної своєї високості, / їх погляди були такі щасливі, / і горді, й приязні (Українка 332) або Він так проїхався по місту, / неначе для розривки римська пані, щось побалакав там своїм звичаєм, / напався на дрібних купців при храмі, та знов до Лазаря свого вернувся/серед жінок розводить мляві жалі/ про те, щовін рокований на згубу, / що з друзями йому не довго бути... (Українка 335) .

Стан психічного дискомфорту героя, породжений невідповідністю між очікуваним і реальністю, засвідчують експресиви у формі окликівстверджень i заперечень, що виконують ще й функцію пояснення, уточнення розпочатої думки: Авжеж, як всі! / Не кращий анітрошечки! (Українка 326); Неправда! (Українка 327); Отож! Отож! (Українка 330); Не так се просто! (Українка 333). Hi, він не був великий! То велика / була його жадоба і пиха! (Українка 335); Не говори мені про те жіноцтво! (Українка 337). Так ампліфікація окличних конструкцій стверджувального плану в поєднанні з епекгезою виконує, на наш погляд, роль своєрідних формул самонавіювання, якими особа намагається переконати себе в правильності вчиненого: Так! Я продав! / А він мене ограбував! Hi, гірше! / 
Він одурив мене! (Українка 330); Мана! / Не царство Боже, ні! - скоріше пекло / було у тім гурті! Яка там заздрість, / ти й здумати не можеш! (Українка 337); I він мене теж зрадив! (Українка 340).

Свідченням когнітивного дисонансу, зовнішнім виявом якого стає експресія, $є$ й риторичні запитання в репліках персонажа: $А$ як би й так?! / Ти думаєш, боюсь я сього слова? “Продав! Продав!” Хто дарма віддає, / той ліпше робить? (Українка 327). Очікування Юди не справдились, що породило комплекс негативних емоцій і психологічний дискомфорт: Нехай би й так! А я ж обдерти дався / до нитки, до шага, - і що ж я мав? / Яку я втіху мав? <...> I що я чув за те? Якеє слово? (Українка 329). Саме пошук шляхів досягти нового, бажаного позитивного результату й репрезентує кумуляція питальних конструкцій, на які герой відповіді не потребує: $A$ що ж було? Мені довіку жити жебрацьким хлібом? / Вік поневірятись, / пороги оббиваючи в людей? <...> / 3 рукою довгою, з язиком довгим поміж людьми появою ходити? (Українка 328-329); Куди б се я пішов? У Каріот? / Просити хліба у тії голоти, / що з рук моїх добро моє посіла? / Щоб там собак на мене нацькували? (Українка 336).

Висновки та перспективи дослідження. Отже, будучи в суголоссі 3 віяннями часу, свою активну зацікавленість психологією Леся Українка реалізує в драматичній поемі «На полі крові», розгортаючи обшир почуттів та емоцій у двох планах: через авторські зауваги й мовлення самого героя.

У ремарках для відтворення психічного стану письменниця активно послугується екстралінгвальнми засобами - мовчання, паузи, сміх, обірваність й незавершеність фраз, тривалість реплік. Використання елементів просодики, зокрема темпу мовлення, голосових характеристик, інтонаційних малюнків й прийому мовної гри (пародіювання) та опису динамічної експресії (міміки й погляду, виразові рухів) уможливило презентацію динаміки рівнів почуттєвості героя.

Вербальні інструменти експлікації почуттєво-емоційної сфери персонажа представлені лексичним, граматичним і стилістичними рівнями. В мовленні Юди домінує просторічна лексика й фразеологічні одиниці негативного маркування. Стан депресії, екзальтації, афекту на синтаксичному рівні відтворюють різні за величиною, будовою й ускладненнями репліки у формі окликів-стверджень, заперечень і риторичних запитань.

Компаративні конструкції з лексичними експресивами, епітетні характеристики для створення констрасту, ампліфікація дій і станів негативної семантики, увага до семантичних нашарувань лексем i їx авторська конотація, апосіопеза й епекгеза в будові реплік - усе це разом із зазначеним вище свідчить про великий арсенал мовних засобів, якими Леся Українка розгортає внутрішній стан героя. Пізнання цього арсеналу, встановлення в ньому домінантних інструментів розглядаємо як завдання для наступних досліджень. 


\section{Список використаної літератури}

Богдан, Світлана. Методи й методика лінгво-стилістичних досліджень: методичні рекомендації для студентів-філологів. Луцьк, 2011.

Леонтьев, Алексей. «Потребности, мотивы, эмоции». Психология эмоций: Тексты, под ред. В. К. Вилюнаса, Ю. Б. Гиппенрейтера. Москва: Издательство Московского университета, 1984.

Косач-Кривинюк, Ольга. Леся Українка. Хронологія життя і творчости. Луцьк: Волинська обласна друкарня, 2006.

Мацько, Любов, і Сидоренко, Олеся. «Лінгвостилістичний погляд на мовний світ Лесі Українки». Лінгвостилістичні студії, вип. 1, 2014, с. 135-45.

Немов, Роберт. Психология. Москва: Просвещение, 1990.

Новий тлумачний словник української мови. У 4 т., укл. В. Яременко, і О. Сліпушко. Київ: Аконіт, 1999.

Пуряєва, Наталія. Словник церковно-обрядової термінології. Львів: Свічадо, 2001.

Романов, Сергій. Леся Українка й Олександр Олесь на порубіжні часів, світів, ідентичностей: монографія. Луцька: Вежа-Друк, 2017.

Словарь української мови, за ред. Б. Грінченка. В 4 т. Київ: Наукова думка, 1996-1997.

Словник іншомовних термінів, укл. С. М. Морозов, Л. М. Шкарапута. Київ: Наукова думка, 2000.

Словник тропів і стилістичних фігур, автор-укл. В. Ф. Святовець. Київ: ВЦ «Академія», 2011.

Спиноза, Бенедикт. «О происхождении и природе аффектов». Психология эмоций: Тексты, под ред. В. К. Вилюнаса, Ю. Б. Гиппенрейтера. Москва: Издательство Московского университета, 1984.

Українка, Леся. Твори. В 2 т. Т. 2. Київ: Наукова думка, 1987.

\section{References}

Bohdan, Svitlana. Metody y metodyka linhvo-stylistychnykh doslidzhen. Lutsk, 2011.

Leont'ev, Aleksej. "Potrebnosti, motivy, jemocii". Psihologija jemocij: Teksty, edited by V. K. Viljunasa, Ju. B. Gippenrejtera. Moskva: Izdatel'stvo Moskovskogo universiteta, 1984.

Kosach-Kryvyniuk, Olha. Lesia Ukrainka. Khronolohiia zhyttia i tvorchosty. Lutsk: Volynska oblasna drukarnia, 2006.

Matsko Lyubov, Sydorenko Olesya. "The Linguistic view on World Language Lesya Ukrainka's". Linguostylistic Studies, iss. 1, 2014, pp. 135-45.

Nemov, Robert. Psihologija. Moskva: Prosveshhenie, 1990.

Novyi tlumachnyi slovnyk ukrainskoi movy. 4 vols, edited by V. Yaremenko, and O. Slipushko. Kyiv: Akonit, 1999.

Puriaieva, Nataliia. Slovnyk tserkovno-obriadovoi terminolohii. Lviv: Svichado, 2001.

Romanov, Serhii. Lesia Ukrainka y Oleksandr Oles na porubizhni chasiv, svitiv, identychnostei: monohrafiia. Lutska: Vezha-Druk, 2017.

Slovar ukrainskoi movy, edited by B. D. Hrinchenko. 4 vols. Kyiv, 1907-1909.

Slovnyk inshomovnykh terminiv, edited by S. M. Morozov, L. M. Shkaraputa. Kyiv: Naukova dumka, 2000.

Slovnyk tropiv i stylistychnykh fihur, edited by V. F. Sviatovets. Kyiv: VTs "Akademiia", 2011.

Spinoza, Benedikt. "O proishozhdenii i prirode affektov". Psihologija jemocij: Teksty, edited by V. K. Viljunasa, Ju. B. Gippenrejtera. Moskva: Izdatel'stvo Moskovskogo universiteta, 1984.

Ukrainka, Lesia. Tvory. 2 vols. Vol. 2. Kyiv: Naukova dumka, 1987. 